\title{
Kan grammatiske konstruktioner have semantisk prosodi?
}

\author{
Kim Ebensgaard Jensen
}

\begin{abstract}
Drawing on a soft interpretation of the construction-grammatical notion of the lexicon-syntax continuum, this paper explores whether grammatical constructions can be said to display patterns of semantic prosody and discusses ways in which constructional semantic prosody as a theoretical construct would need to be defined such that two types of constructional semantic prosody are posed: inner semantic prosody, which applies to collocational fields in schematic positions in a construction, and outer semantic prosody, which applies to collocational fields in the construction's co-text. Two admittedly sketchy and exploratory empirical investigations suggest that inner semantic prosody might be a viable theoretical concept, while outer semantic prosody does not seem to be viable.
\end{abstract}

Nøgleord: Frankenstein-forskning, kollokation, konstruktionsgrammatik, korpuslingvistik, semantisk prosodi/præference

\section{Introduktion}

Semantisk prosodi blev først opdaget, da korpuslingvistikken gjorde sit indtog (f.eks. Sinclair 1991, 1996; Louw 1993, 2000; Bublitz 1996; Hunston \& Francis 1999; Stubbs 2001; Tognini-Bonelli 2001; Stewart 2010; Begagić 2013). Det er nemlig et fænomen, som gemmer sig i kollokationsmønstre og dermed ikke kan ses med det blotte øje.

Semantisk prosodi er hidtil primært blevet tilgået i forskningen som et leksikalt fænomen, der har med attitudinel betydning at gøre. I denne artikel undersøges det med den ususbaserede konstruktionsgrammatik som udgangspunkt, om semantisk prosodi eller noget, der ligner, også findes i grammatikken. Skønt artiklen først og fremmest tjener til at fremstille nogle teoretiske begreber, så trækker den på empiri i form af undersøgelser af 
to slags kvantificerende nominalkonstruktioner på engelsk - nemlig a great deal of $\mathcal{N}$ versus a great many $\mathcal{N}$ og partitiverne bunch of $\mathcal{N}$, cluster of $\mathcal{N}$, load of $\mathcal{N}$, pile of $\mathcal{N}$ og stack of $\mathcal{N}$. Det skal påpeges, at forskningen, som ligger til grund for denne artikel, er eksplorativ på en nærmest Frankenstein-agtig facon og på ingen måde skal anses som endegyldig. Tværtimod er der tale om de første famlende skridt i retning af noget, som kunne gå hen og blive en hypotese, der, når det punkt er nået (eller hvis det punkt nås), kan testes og falsificeres eller verificeres.

Denne artikel er struktureret som følger. Efter en gennemgang af semantisk prosodi i afsnit 2, hvor termen 'defineres' og fænomenet diskuteres, præsenteres i afsnit 3 de basale principper i konstruktionsgrammatikken. Herefter fremsættes i afsnit 4 en præ-hypotese for konstruktionel semantisk prosodi, som trækker på diskussioner i afsnit 2 og 3. I afsnit 5 beskrives den korpusbaserede metode, som gøres brug af, og selve analyserne præsenteres $i$ afsnit 6 .

\section{Semantisk prosodi}

Louw (1993: 157) definerer semantisk prosodi som en "consistent aura of meaning with which a form is imbued by its collocates". Ligeledes beskriver Bublitz (1996: 9) semantisk prosodi som en "a halo or profile" som er "based on a semantically consistent set of collocates". Stubbs (2001: 65), som foretrækker termen 'diskursprosodi', definerer denne som 'a feature which extends over more than one unit in a linear string". Tognini-Bonelli (2001) skriver, at sprogbrugerens valg "will involve the more local and grammatical constraints around the word, but will also include a perhaps more remote semantic preference and its correspondend on the pragmatic side, semantic prosody", og Hunston \& Francis (1999: 137) påpeger, at "a word may be said to have a particular semantic prosody if it can be shown to cooccur typically with other words that belong to a particular semantic set."

Man kan af disse definitioner ${ }^{1}$ udlede, at semantisk prosodi er en type betydning hos det enkelte ord, som transcenderer dettes formelle grænser og manifesteres som mønstre i ordets kollokationsfelt.

Indtil videre har forskning i semantisk prosodi begrænset sig til attitudinel betydning (f.eks. Sinclair 1991, 1996; Louw 1993, 2000; Bublitz 1996; Stubbs 2001; Tognini-Bonelli 2001). Princippet her er ganske simpelt:

1. Se Stewart (2010: 6-20) for en mere detaljeret gennemgang af centrale definitioner i faglitteraturen om semantisk prosodi. 
- Ord med primært negativt klingende kollokater har negativ semantisk prosodi.

- Ord med primært positivt klingende kollokater har positiv semantisk prosodi.

- Ord med kollokater, der hverken klinger negativt eller positivt, har neutral prosodi.

Stubbs (2001: 65) går så langt som at kategorisere semantiske prosodier som funktionelle diskursmønstre: "Since they are evaluative, prosodies often express the speaker's reason for making the utterance, and therefore identify functional discourse units". Dette er specielt interessant i forbindelse med ususbaseret konstruktionsgrammatik, hvor sådanne diskursmønstre ikke blot er funktionelle men også kan være kategoriske funktionstræk hos konstruktioner.

\subsection{Metodologiske udfordringer}

Opdagelsen af semantisk prosodi er et vigtigt bidrag til sprogvidenskaben men er ikke uden problemer. Der er for eksempel den metodologiske hage, at de prosodier, man kan udvinde, afhænger af, hvordan man indstiller sin concordancer $^{2}$ med hensyn til minimumsfrekvenser og kollokationsvinduets vidde. Hvis man opererer med lav minimumsfrekvens og en bred vidde, vil man finde flere kollokater, end hvis man opererer med høj minimumsfrekvens og en smal vidde.

Derudover er begrænsningen til attitudinel betydning problematisk på mindst to punkter. Der kan være et for stort element af subjektivitet fra analytikerens side, når det afgøres, om kollokater er positive, negative eller neutrale, og den attitudinelle betydning kan i varierende grad være en refleksion af analytikerens egne holdninger. Der kan også være ideologibestemte attituder, som analytikeren af samme årsag overser.

\subsection{Afgraensningsudfordringer}

Der skelnes traditionelt mellem semantisk prosodi og semantisk præference (Partington 2004: 149). Hvor semantisk prosodi dækker attitudinel

2. Concordancer er den engelske betegnelse for et computerværktøj, som bruges til at lave konkordanser (en konkordans er et sæt konkordanslinjer). For at undgå forvirring bruger jeg den engelske term, når jeg refererer til computerværktøjet.. 
betydning, som kan udledes af kollokationsfelter, dækker semantisk præference specifikke semantiske klasser, der kan udledes af kollokationsfelter. For eksempel finder Stubbs (2001: 89-95), at det engelske verbum undergo blandt andet har følgende semantiske præferencer: 'medicin' (treatment, hysterectomy, surgery osv.), 'prøver' (examination, training osv.), 'forandring' (dramatic changes, a historic transformation osv.). Semantiske præferencer er således ganske specifikke semantiske grupperinger af kollokater. I modsætning er semantiske prosodier, i og med at de har med attitudinel betydning at gøre, ret abstrakte. Forholdet mellem de to er, at semantiske prosodier udledes af mønstre blandt semantiske præferencer (Begagić 2013). Stubbs (2001: 89-95) tilskriver for eksempel undergo en negativ semantisk prosodi, da de semantiske præferencer alle underordner kollokater med reference til situationer, som på den ene eller anden måde er ubehagelige. Et problem med denne skelnen er placeringen af selve skillelinjen. Hvornår bliver semantiske mønstre i et kollokationsfelt så abstrakte, at der ikke længere er tale om præferencer men om prosodier? Det giver måske mere mening at opgive denne skelnen og i stedet operere med grader eller niveauer af semantisk prosodi. I erkendelse af, at der ikke kan sættes en klar skillelinje, opereres der i denne artikel med semantisk prosodi som betegnelse for alle typer semantiske mønstre og grupperinger på kollokationsniveau.

Det er også en potentielt problematisk begrænsning, at semantisk prosodi ses som et leksikalt fænomen og ikke et bredere syntaktisk-leksikalt fænomen som sådan. Det ville i hvert fald, som påpeget andetsteds (Jensen 2017), give mening i mange samtidige funktionalistiske tilgange at undersøge, hvorvidt grammatiske størrelser også kan have semantisk prosodi.

\section{Konstruktionsgrammatik}

Den teoretiske ramme for dette studie er konstruktionsgrammatikken (Fillmore et al. 1988; Goldberg 1995; Croft 2001) - nærmere betegnet den ususbaserede konstruktionsgrammatik (Croft \& Cruse 2004: 291-327; Patten 2014). En central antagelse i konstruktionsgrammatikken er, at en konstruktion er en konventionel semiotisk enhed bestående af form og betydning, og betydning skal her forstås meget bredt som dækkende både semantisk og diskurs-pragmatisk funktion.

Sprogsystemet ses som et kognitivt netværk af konstruktioner (Croft \& Cruse 2004: 318-323), som i den ususbaserede konstruktionsgrammatik et emergent system (jf. Hopper 1998), der tilegnes induktivt (jf. Tomasello 2003). Det vil sige, at systemet i sprogbrugeren vokser ud af usus. Patten 
(2014: 91) fremstiller en elegant og præcis beskrivelse af den ususbaserede konstruktionsgrammatiks principper:

On this model, humans are not innately programmed with grammatical knowledge; instead, all aspects of language are learned from the input (or rather from the speaker's linguistic experiences). Both language learning and language change involve the speaker inductively generalizing over instances to form mental schemas (or constructions) which are represented in the language system. On a usage-based model then, constructions are simply conventionalized chunks of linguistic knowledge ... From this, it follows that the storage and organization of grammatical knowledge is dependent on, and can change according to, patterns of use

Således er der i sprogsystemet plads til strukturel redundans, og viden om relevante sprogbrugskontekster (ko-tekstuelle mønstre, genrer/registre, sprogbrugssituationer osv.) indgår i sprogsystemet. Logikken ligger i den emergente karakter, som sprogsystemet gives: hvis en struktur bruges hyppigt i en vis kontekst, antages det, at sprogbrugeren ved, at denne konstruktion bruges hyppigt i denne kontekst, og dermed er denne viden en del af sprogbrugerens sproglige kompetence. En konstruktion kan være fuldt skematisk (alle dens positioner er leksikalt åbne) eller være fuldt fikseret (Fillmore et al. 1988: 505). Den samme konstruktion kan også indeholde både skematiske og fikserede elementer.

Flere sprogforskere i ususbaseret lingvistik argumenterer, at sproget er et komplekst adaptivt system (Beckner et al. 2009). Et sådant system er emergent og baseret på interaktioner mellem adskillige agenter; i disse mange interaktioner opstår mønstre, og via kognitive generaliseringsprocesser ligger disse til grund for et emergent system i sprogbrugeren, der påvirker fremtidige interaktioner i et såkaldt feedback loop (Frank 2015: 495). I et konstruktionsgrammatisk perspektiv gør dette feedback loop, at konstruktionsnetværket er et heterogent distribueret, dynamisk og adaptivt system, hvor kollokationsmønstre sagtens kan indgå i sprogbrugerens kompetence.

Eftersom konstruktioner ses som form-betydningspar, har konstruktionsgrammatikere bortkastet den traditionelle skarpe adskillelse mellem syntaks og leksikon og opererer i stedet med et leksikon-syntakskontinuum, hvor atomiske konstruktioner (dvs. morfemer og leksemer) findes ved den ene pol, og komplekse konstruktioner (dvs. multienhedsstrukturer) findes ved den anden (Goldberg 1995: 7; Croft 2001: 17). Kontinuumidéen kan 
virke meget kontroversiel, hvis man tolker den som udtryk for, at atomiske og komplekse konstruktioner på alle områder er funktionalitetsidentiske. En blødere tolkning er dog, at kontinuumidéens formål bare er at understrege, at der findes form-betydningspar i både leksis og syntaks til trods for strukturkompleksitetsforskellene, men at dette ikke betyder, at atomiske og komplekse konstruktioner er funktionalitetsidentiske. På den måde kan man stadig sondre mellem leksikal og grammatisk funktionalitet uden at skulle opgive idéen om, at grammatiske strukturer som konventionelle semiotiske enheder. Denne artikel bekender sig til denne bløde tolkning.

\section{En pra-hypotese om konstruktionel semantisk prosodi}

I dette afsnit fremstiller jeg en 'præ-hypotese' om konstruktionel semantisk prosodi. En ligefrem præ-hypotese kunne være: 'en grammatisk konstruktion kan udvise semantisk prosodi'. Denne formulering er dog for simpel.

Man skal huske, at syntaktiske konstruktioner er komplekse og dermed kan indeholde skematiske positioner. Dette betyder, at der kan være et kollokationsfelt i hver skematisk position udover de kollokater, som findes i konstruktionens ko-tekst. Derfor må man nødvendigvis skelne mellem indre semantisk prosodi og ydre semantisk prosodi ${ }^{3}$ samt indre og ydre kollokationsfelter og indre og ydre kollokater. Med 'ydre kollokater' menes der ord, som findes i konstruktionens venstre og højre ko-tekst (dvs. til venstre og højre for konstruktionen). Med 'indre kollokater' menes der ord, som findes i en skematisk position i en konstruktion (så som, for eksempel N-positionen $i$ a great deal of $\mathcal{N}$ ). Det ydre kollokationsfelt dækker således samtlige af konstruktionens ydre kollokater, og det er her, vi finder den ydre semantiske prosodi. Det indre kollokationsfelt dækker samtlige af konstruktionens indre kollokater, og her finder vi den indre semantiske prosodi. Et bedre udgangspunkt er således en toleddet præ-hypotese:

- En grammatisk konstruktion kan udvise indre semantisk prosodi

- En grammatisk konstruktion kan udvise ydre semantisk prosodi

Her er der mulighed for at tage højde for eventuelle fundamentale forskelle på kollokationsmønstre i indre skematiske positioner og ydre ko-tekster.

3. Jf. "inner" og "outer constructional properties" (Fillmore 1988) 
Begrebet 'indre semantisk prosodi' kan måske virke lidt selvmodsigende, men vi skal her huske, at, hvor selve den skematiske position i en konstruktion er del af konstruktionens formelle struktur, så er leksemerne, der udgør positionens kollokationsfelt del af konstruktionens ko-tekst. Derfor mener jeg godt, at man kan tillade sig at operere med konceptet 'indre semantisk prosodi'.

\section{Data og metode}

De to empiriske undersøgelser trækker på data fra Davies' (2016) Corpus of Contemporary American English (COCA), som dokumenterer amerikansk engelsk i perioden 1990-2015. COCA består af 533.788.932 ord og er delt op i følgende tekstgenrer: akademiske tekster, dagblade/magasiner, avisartikler, fiktion og tale. De to undersøgelser trækker på specifikke dele af korpusset, som specificeres i næste sektion; fra disse hentes alle forekomster af konstruktionerne ned i en konkordans (der er således ikke en specificeret vidde, da kollokationsvinduet svarer til det af concordanceren specificerede højre og venstre ko-tekst), og ikke-forekomster sorteres fra. Efterfølgende består metoden af følgende skridt:

- Konkordansen deles op i tre separate dele: indre kollokater, ydre kollokater i venstre ko-tekst og ydre kollokater i højre ko-tekst.

- Alle kollokater lemmatiseres i Bicks (1996-2016) 'flat structure parser'.

- Rå frekvenslister genereres for lemmatiserede indre kollokater samt ydre kollokater i højre ko-tekst og i venstre ko-tekst.

- Indre kollokater analyseres desuden semantisk og inddeles i semantiske grupperinger, der kvantificeres i procenter. ${ }^{4}$ Semantiske grupperinger, eller semantiske klasser, er grupperinger af leksemer (i dette tilfælde blandt kollokaterne), som overlapper semantisk i en sådan grad, at de kan siges at være semantisk relaterede. I denne artikel baseres den semantiske gruppering på semantiske felter, således at kollokater, der kan placeres i samme semantiske klasse (f.eks. kan substantiverne shirt, dress, og trousers placeres i et 'apparel'-felt da deres referenter alle er beklædningsgenstande, hvorfor de kan samles under den semantiske klasse 'apparel').

4. Ideelt set burde de ydre kollokater også analyseres semantisk, men dette er en ekstremt tidsskrævende proces, så det har ikke været muligt. 
- Semantiske prosodier udledes af frekvenslisterne.

- Yderligere ko-tekstuelle mønstre identificeres i en ordklyngeanalyse i Anthony (2014).

Denne metode er dybt eksplorativ på en lad-os-se-om-det-overhovedetvirker-facon og er ikke replikerbar. Der er som sagt tale om en slags Frankenstein-forskning for at teste vandene, og for at kunne bedrive fyldestgørende forskning i konstruktionel semantisk prosodi skal der en mere systematisk metode til. Der skal dog tages skridt hen imod sådan en metode, og her er vores Frankenstein-forskning et sådant skridt.

En redegørelse for valget af a great deal of $\mathcal{N}$, a great many $\mathcal{N}$ og de fem partitivkonstruktioner som empiri er på sin plads. Alle konstruktioner er nominalkonstruktioner og har ret substantielle semantiske funktioner, hvilket muliggør de semantiske forbindelser, der ligger til grund for kollokationer:

- A great deal of $\mathcal{N}$, a great many $\mathcal{N}$ : Disse konstruktioner er intensiverende kvantificerende nominalkonstruktioner, hvis kommunikative funktion svarer til en hel del $\mathcal{N}$ på dansk (Hjulmand \& Schwarz 2015: 137). Desuden er der den semantiske forskel, at a great deal of $\mathcal{N}$ udtrykker ubundne masser, hvor a great many $\mathcal{N}$ udtrykker multiplekser (Talmy 2000: 48-49) af bundne og tællelige enheder; denne semantiske forskel afspejles i, at a great deal of $\mathcal{N}$ foretrækker utællelige substantiver, hvor a great many $\mathcal{N}$ foretrækker tællelige substantiver.

- Bunch of $\mathcal{N}$, cluster of $\mathcal{N}$, load of $\mathcal{N}$, pile of $\mathcal{N}$, stack of $\mathcal{N}$ : Disse hører til en kategori af partitivkonstruktioner, som har det, man kan kalde en konstellationsfunktion. Hver partitiv udtrykker en fysisk multipleks konstellation som mindre enheder kan arrangeres i. Disse konstellationer er henholdsvis 'bundt', 'klynge', 'læs', 'bunke' og 'stak'.

I modsætning til mere abstrakte konstruktioner med vagere semantisk indhold er der en chance for, at disse konstruktioner kan indgå i semantiske forbindelser med både indre og ydre kollokater, hvilket gør den specielt egnede til Frankenstein-forskning af den karakter, som denne artikel bygger på. 


\section{Undersøgelser}

\subsection{Semantisk prosodi $i$ a great deal of $\mathbf{N} o g$ a great many $\mathbf{N}$}

Denne undersøgelse er baseret på data fra perioden 2010-2015 i COCA. Denne del af korpusset består af 121.375.052 ord. I denne del fandtes 841 forekomster af a great deal of $\mathcal{N}$ og 94 forekomster af a great many $\mathcal{N}$. De få forekomster skyldes faldende brug på amerikansk engelsk siden 1800-tallet af begge konstruktioner (Jensen 2016).

I Tabel 1 ses de 20 hyppigste indre kollokater i a great deal of $\mathcal{N}$.

\begin{tabular}{ccc|ccc}
\hline & Kollokat & Frekv. & & Kollokat & Frekv. \\
\hline 1 & time & 70 & 11 & pain & 10 \\
2 & money & 48 & 12 & pressure & 10 \\
3 & attention & 27 & 13 & sympathy & 10 \\
4 & work & 22 & 14 & confidence & 9 \\
5 & information & 18 & 15 & frustration & 9 \\
6 & research & 17 & 16 & uncertainty & 9 \\
7 & effort & 16 & 17 & data & 7 \\
8 & respect & 14 & 18 & debate & 7 \\
9 & thought & 12 & 19 & discussion & 7 \\
10 & trouble & 11 & 20 & energy & 7 \\
\hline
\end{tabular}

Tabel 1: Top 20 indre kollokater i a great deal of $\mathcal{N}$

Ikke overraskende (jf. Hjulmand \& Schwarz 2015: 137; Jensen 2016) har kollokaterne det fælles semantiske træk, at de refererer til svært kvantificerbare størrelser, hvilket afspejles i, at mange er prototypisk utællelige substantiver. Figur 1 redegør for den semantiske analyse de indre kollokater. 


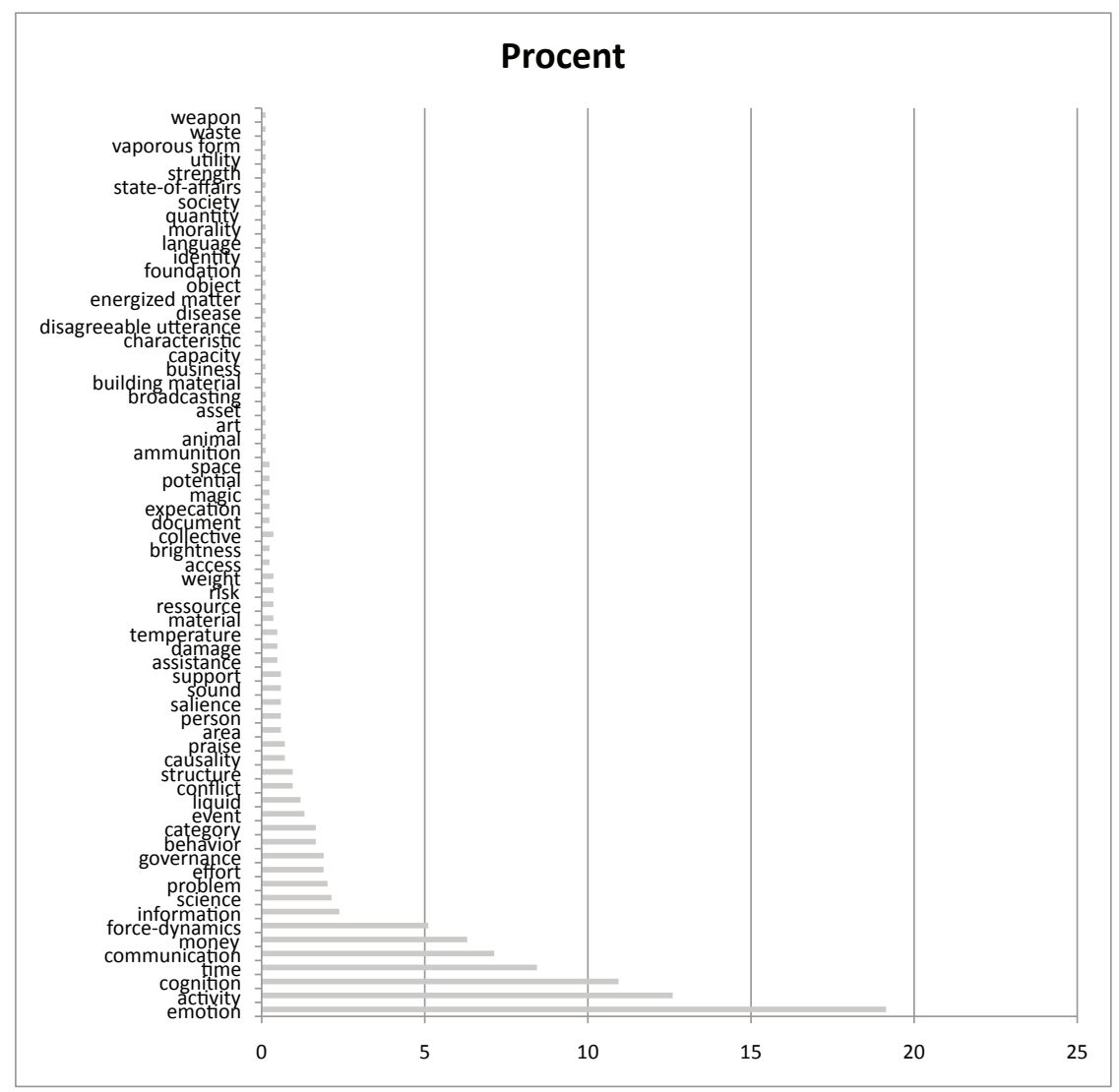

Figur 1: Semantisk analyse af indre kollokater i a great deal of $\mathcal{N}$

I princippet er hver klasse en semantisk prosodi. Zoomer man lidt ud, kan det argumenteres, at nogle mere abstrakte indre semantiske prosodier kan udledes. En prominent prosodi lader til at være en 'tanke/følelse'-prosodi, som underordner klasserne 'emotion' og 'cognition'. Sammenholder man dette med Tabel 1, ser man en diskrepans mellem de enkelte kollokater og de semantiske klasser. Det hyppigste kollokat er time; den hyppigste klasse er 'emotion'. Klassen 'time', som underordner tidsnominaler, er tredjehyppigst. Hvor time som er det hyppigste kollokat, har alle kollokaterne, som underordnes af 'emotion', samlet en højere frekvens end dem under klassen 'time'. En 'handling/hændelse'-prosodi dækker kollokater, som udtrykker handlinger, aktiviteter, hændelser og lignende. Denne underordner følgende semantiske klasser: 'activity', 'force-dynamics', 'behavior' 
og 'event'. Endnu en prosodi kan kaldes 'kommunikation', som består af klasserne 'communication', 'disagreeable utterance' og muligvis 'conflict'. Sammen indikerer Figur 1 og Tabel 1, at a great deal of $\mathcal{N}$ ikke kun har en præference for utællelige substantiver, men også for forskellige semantiske klasser, hvoraf nogle kan klynges sammen til mere abstrakte semantiske prosodier. Desuden underordner de klasser, som udgør enkelte af de mere abstrakte prosodier, kollokater, hvis referenter ikke nødvendigvis er svært kvantificerbare. For eksempel kan handlinger, hændelser og aktiviteter ikke siges at være utællelige. A great deal of $\mathcal{N}$ synes at have en omfortolkende funktion i forbindelse med 'handling/hændelse'-prosodien, hvor ellers kvantificerbare handlinger, hændelser og aktiviteter omfortolkes som masseagtige og intensiveres via konstruktionens semantik. Dette illustrerer, hvor vigtigt det er, at tage højde for både de enkelte kollokater og de semantiske klasser, de udgør (jf. Croft 2003: 85, Tomasello 2003: 178).

Der synes at være noget, der minder om semantiske prosodier på spil, men hvad med ydre semantiske prosodier? Tabel 2 redegør for de 45 hyppigste ydre kollokater.

\begin{tabular}{|c|c|c|c|c|c|c|c|c|c|c|c|c|c|c|}
\hline & Kollokat & Frekv.(V) & Frekv.(H) & Frekv. & & Kollokat & Frekv.(V) & Frekv.(H) & Frekv. & & Kollokat & $\begin{array}{c}\text { Frekv.(V } \\
)\end{array}$ & Frekv.(H) & Frekv. \\
\hline 1 & be & 386 & 235 & 621 & 16 & go & 16 & 27 & 43 & 31 & see & 13 & 13 & 26 \\
\hline 2 & $\mathrm{i}$ & 179 & 108 & 287 & 17 & well & 27 & 14 & 41 & 32 & need & 12 & 14 & 26 \\
\hline 3 & number & 129 & 77 & 206 & 18 & also & 23 & 14 & 37 & 33 & show & 14 & 11 & 25 \\
\hline 4 & have & 144 & 57 & 201 & 19 & require & 30 & 5 & 35 & 34 & thing & 10 & 15 & 25 \\
\hline 5 & there & 163 & 24 & 187 & 20 & very & 16 & 18 & 34 & 35 & school & 9 & 16 & 25 \\
\hline 6 & not & 100 & 68 & 168 & 21 & come & 16 & 16 & 32 & 36 & always & 18 & 6 & 24 \\
\hline 7 & say & 38 & 39 & 77 & 22 & give & 25 & 5 & 30 & 37 & great & 12 & 12 & 24 \\
\hline 8 & do & 34 & 42 & 76 & 23 & year & 18 & 12 & 30 & 38 & work & 12 & 12 & 24 \\
\hline 9 & take & 46 & 13 & 59 & 24 & find & 17 & 12 & 29 & 39 & good & 13 & 10 & 23 \\
\hline 10 & know & 33 & 25 & 58 & 25 & get & 15 & 14 & 29 & 40 & learn & 10 & 13 & 23 \\
\hline 11 & make & 28 & 28 & 56 & 26 & student & 12 & 17 & 29 & 41 & little & 9 & 13 & 22 \\
\hline 12 & time & 25 & 29 & 54 & 27 & use & 17 & 10 & 27 & 42 & even & 8 & 14 & 22 \\
\hline 13 & spend & 53 & 0 & 53 & 28 & right & 12 & 15 & 27 & 43 & here & 7 & 14 & 21 \\
\hline 14 & people & 24 & 25 & 49 & 29 & just & 11 & 16 & 27 & 44 & feel & 17 & 3 & 20 \\
\hline 15 & think & 28 & 18 & 46 & 30 & still & 19 & 7 & 26 & 45 & study & 13 & 7 & 20 \\
\hline
\end{tabular}

Tabel 2: Tdre kollokater i a great deal of $\mathcal{N}$ 
Gransker man samtlige ydre kollokater findes der ingen tegn på ydre semantiske prosodier som sådan. Der er dog nogle transitive verber på listen med meget højere venstre-frekvenser end højre-frekvenser; disse kunne være indikatorer på semantiske forbindelser mellem konstruktionen som direkte objekt og de transitive verber. Vi holder os her til spend, feel og take. Ved hjælp af ordklyngeanalyser (se Tabel 3 for et eksempel på et uddrag fra en ordklyngeanalyse) er det muligt at identificere instantieringer, der fungerer som direkte objekt.

\begin{tabular}{cc}
\hline Ordklynge & Frekv. \\
\hline spent a great deal of time in & 3 \\
spent a great deal of time and & 3 \\
spending a great deal of time by & 2 \\
spend a great deal of money to & 1 \\
spend a great deal of time looking & 1 \\
spend a great deal of time exploring & 1 \\
spend a great deal of time helping & 1 \\
spend a great deal of time honing & 1 \\
spend a great deal of time in & 1 \\
spend a great deal of time on & 1 \\
spend a great deal of time raising & 1 \\
spend a great deal of time retrieving & 1 \\
spend a great deal of time together & 1 \\
spend a great deal of time using & 1 \\
spend more time raising a family without & 1 \\
spending a great deal of effort to & 1 \\
spending a great deal of time and & 1 \\
spending a great deal of time in & 1 \\
spending a great deal of time on & 1 \\
spending a great deal of time out & 1 \\
\hline
\end{tabular}

Tabel 3: Ordklyngeanayse af spend som ydre kollokat 
Som fremgår af Tabel 3, synes a great deal of time at være et hyppigt direkte objekt for spend som transitivt verbum i venstre ko-tekst. A great deal of time, a great deal of money, og a great deal of effort er de eneste instantieringer, der fungerer som direkte objekt her. Dette peger på en semantisk forbindelse mellem spend på den ene side og time, money og effort på den anden (disse optræder jo ofte som direkte objekter for spend i nær-idiomatiske strenge), snarere end mellem verbet og a great deal of $\mathcal{N}$. Det samme lader til at gøre sig gældende for feel og take. I Tabel 4 og Tabel 5 ses lister over indre kollokater, når konstruktionen fungerer som direkte objekt for feel og take som ydre venstrekollokater.

Indre kollokater anxiety, guilt, responsibility, sadness, warmth, frustration, sorrow, sympathy, unease, resentment, pressure

Tabel 4: Indre kollokater med feel som ydre venstrekollokat

\begin{tabular}{ll}
\hline \hline Indre kollokater & $\begin{array}{l}\text { pride, time, care, experimentation, planning, pleasure, } \\
\text { work, joy, heat, courage, effort, knowledge, planning, } \\
\text { practice, resilience, soul-searching, comfort, } \\
\text { encouragement, listening }\end{array}$ \\
\hline
\end{tabular}

Tabel 5: Indre kollokater med take som ydre venstrekollokat

Alle kollokater i Tabel 4 udtrykker noget følbart - det være sig følelser (sadness, frustration), temperatur (warmth) eller eksterne kræfter (pressure), hvorfor det giver mening, at de figurerer i direkte objekter for feel. I Tabel 5 ses pride, care og joy, der jo figurerer i de idiomatiske udtryk take pride in, take care to og take joy in; derudover ses en række kollokater, der reflekterer brugen af take med betydningen 'kræve' som i it takes discipline to ('det kræver disciplin at') og it takes planning to ('det kræver planlægning at'). Også her er der snarere tale om en semantisk forbindelse mellem det transitive verbum og de indre kollokater end mellem verbet og konstruktionen.

De 20 hyppigste indre kollokater i a great many $\mathcal{N}$ ses i Tabel 6. 


\begin{tabular}{ccc|ccc}
\hline & Kollokat & Frekv. & & Kollokat & Frekv. \\
\hline 1 & thing & 21 & 11 & charity & 1 \\
2 & people & 12 & 12 & child & 1 \\
3 & indian & 2 & 13 & concert & 1 \\
4 & man & 2 & 14 & cousin & 1 \\
5 & question & 2 & 15 & critic & 1 \\
6 & adult & 1 & 16 & crow & 1 \\
7 & amalgamator & 1 & 17 & day & 1 \\
8 & boat & 1 & 18 & director & 1 \\
9 & case & 1 & 19 & document & 1 \\
10 & change & 1 & 20 & dog & 1 \\
\hline
\end{tabular}

Tabel 6: Top 20 indre kollokater i a great many $\mathcal{N}$

Udover at thing er det hyppigste kollokat, er det iøjefaldende, at mange af kollokaterne refererer til personkategorier (f.eks. adult, director, Indian, child og critic). Konstruktionen lader til at have en indre 'person'-prosodi, som underordner kollokater med reference til personer og personkategorier som semantisk fællestræk. Dette understøttes af den semantiske analyse i Figur 2. 


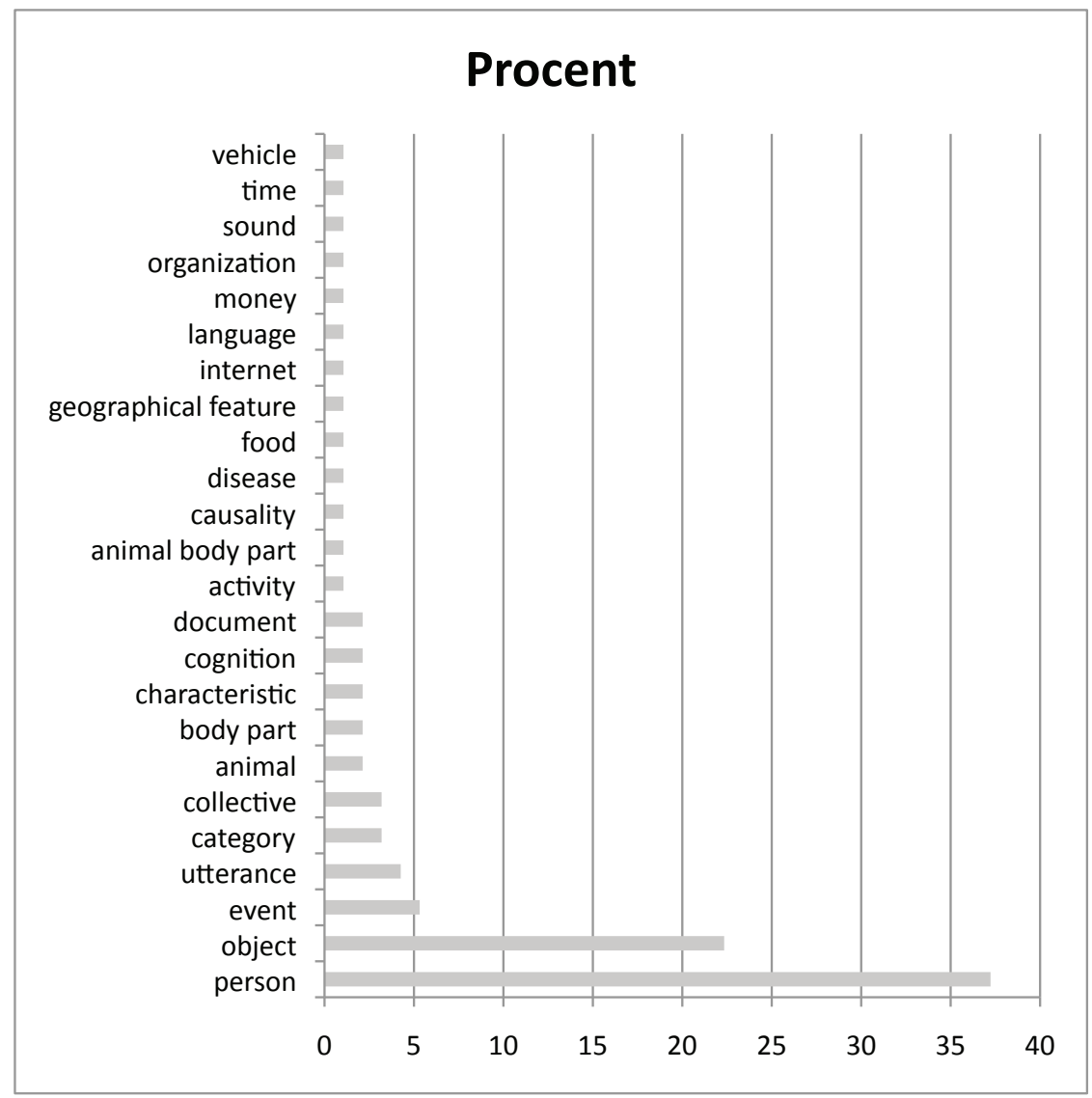

Figur 2: Semantisk analyse af indre kollokater i a great many $\mathcal{N}$

Figur 2 viser, at klassen 'person' er hyppigst, hvilket berettiger et postulat om 'person' som en indre semantisk prosodi. Det er ikke et tilfælde, at størstedelen af de øvrige semantiske klasser i kollokationsfeltet underordner kollokater med kvantificerbare referenter, eftersom a great many $\mathcal{N}$ har en præference for tællelige substantiver (Jensen 2016).

Analysen af ydre kollokater viser ingen tegn på ydre semantiske prosodier. Det skal nævnes, at be, I, there, not og have er de fem hyppigste ydre kollokater, og be, I og have er bemærkelsesværdigt hyppigere i venstre ko-tekst end højre ko-tekst, men ordklyngeanalyserne viser ingen mønstre. 


\subsection{Bunch of $N$, pile of $N$, load of $N$, stack of $N$ og cluster of $\mathbf{N}$}

Denne undersøgelse trækker på data i COCA fra 2015. Denne del af korpusset indeholder 19.950.475 ord. Her fandtes 355 forekomster af bunch of $\mathcal{N}, 90$ af cluster of $\mathcal{N}, 64$ load of $\mathcal{N}, 208$ af pile of $\mathcal{N}$ og 155 af stack of $\mathcal{N}$.

Figurerne 3-7 redegør for distribueringen af semantiske klasser i konstruktionernes indre kollokationsfelter.

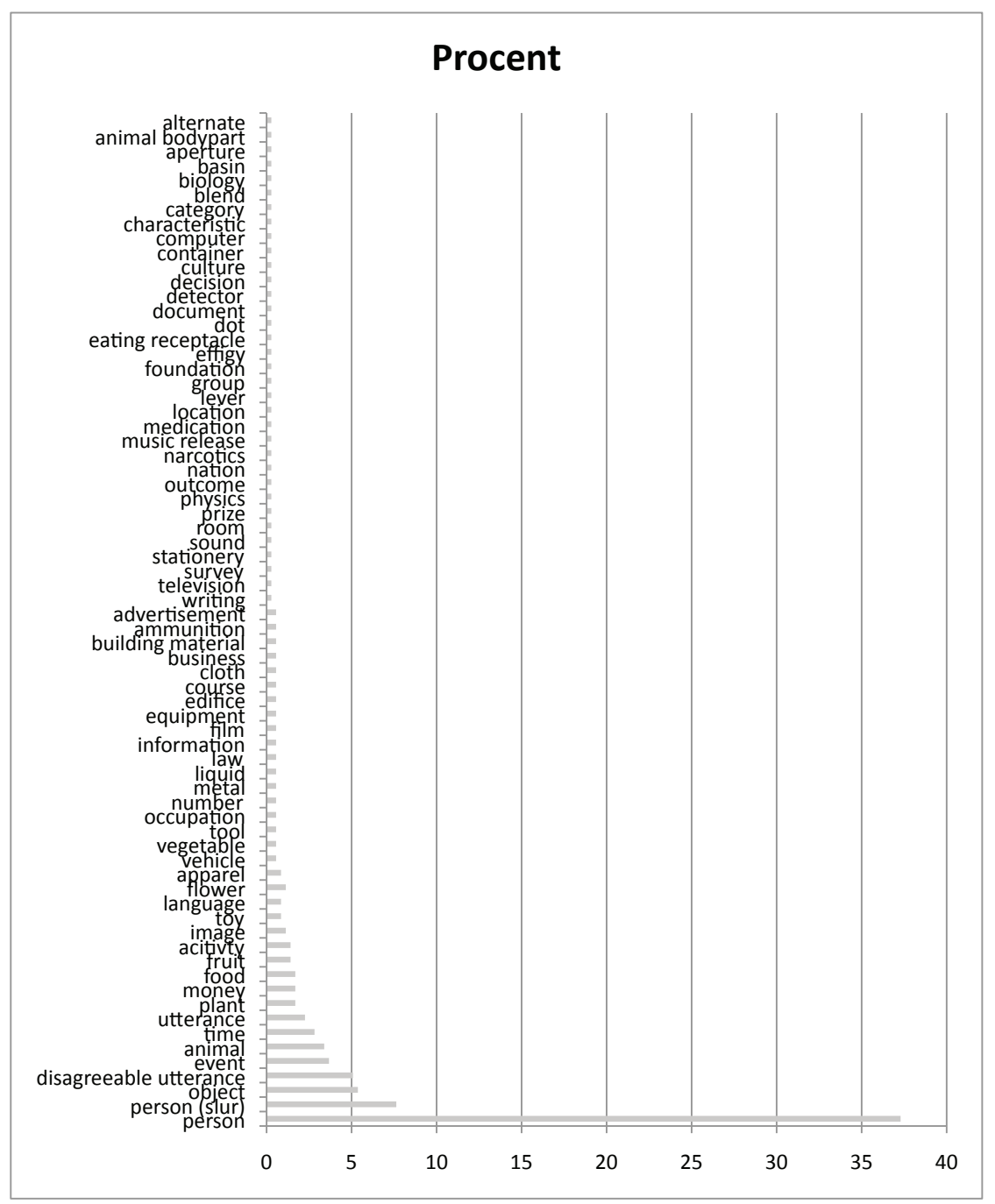

Fig. 3: Semantisk analyse af indre kollokater i bunch of $\mathcal{N}$ 


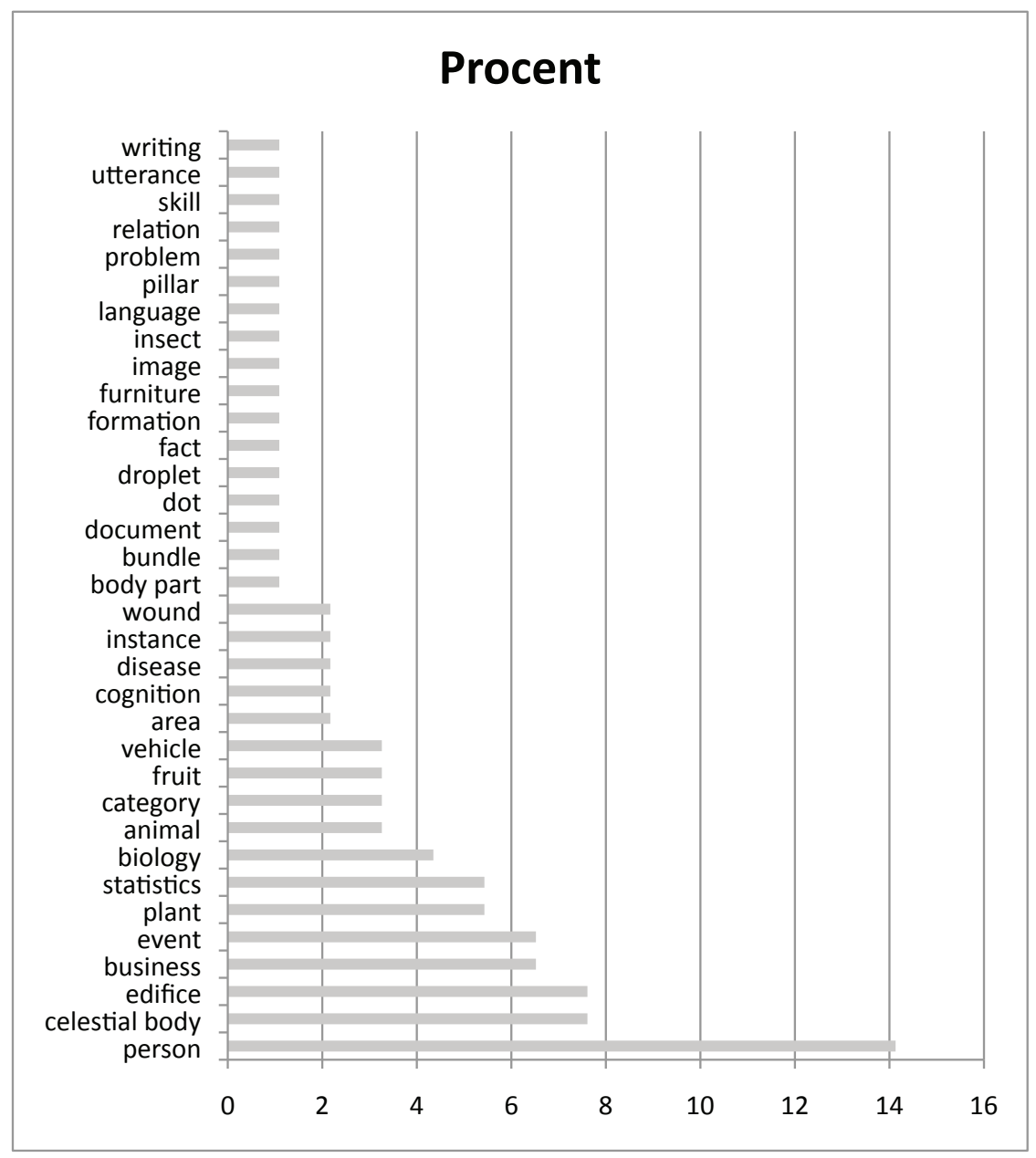

Fig. 4: Semantisk analyse af indre kollokater i cluster of $\mathcal{N}$ 


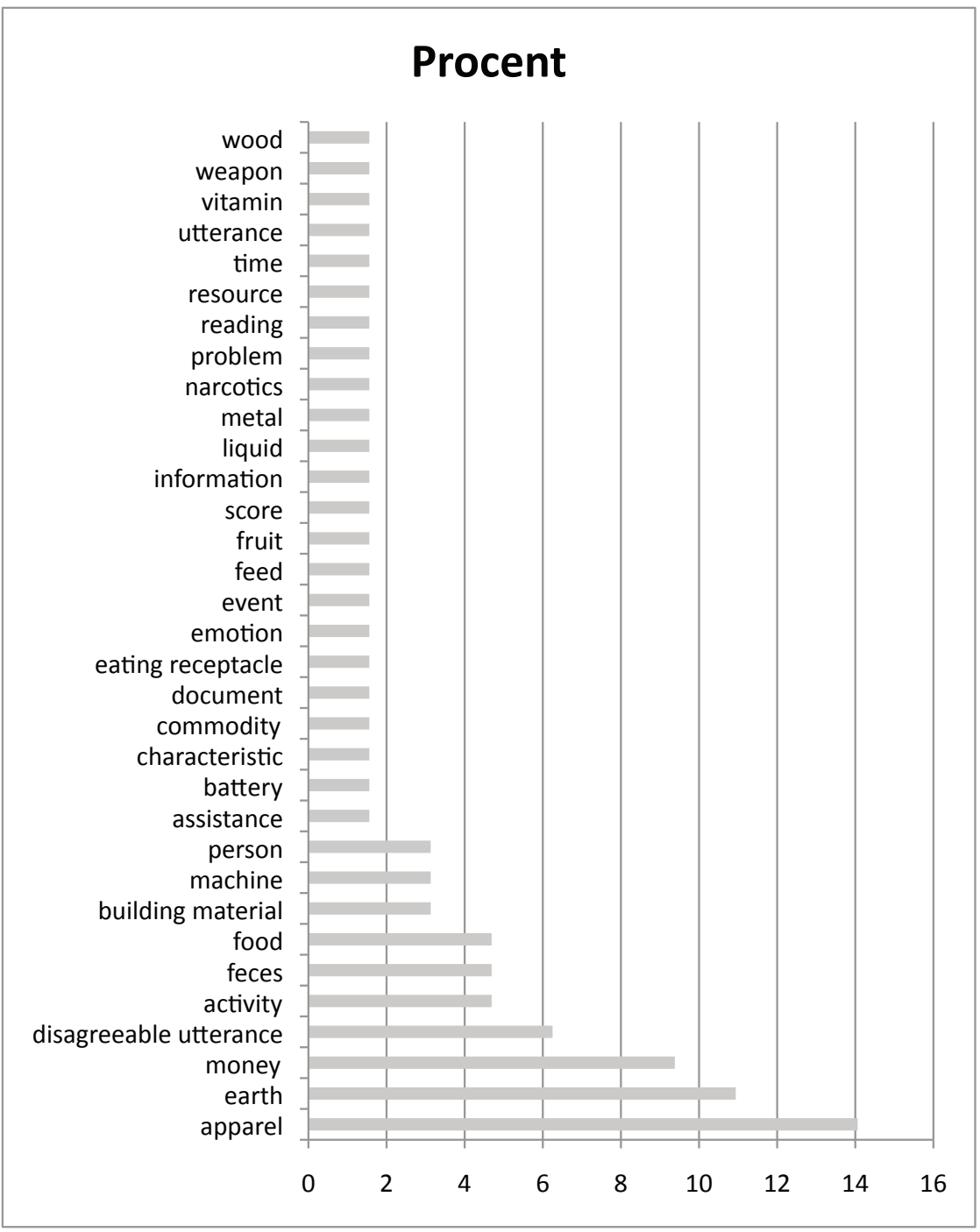

Fig. 5: Semantisk analyse af indre kollokater i load of $\mathcal{N}$ 


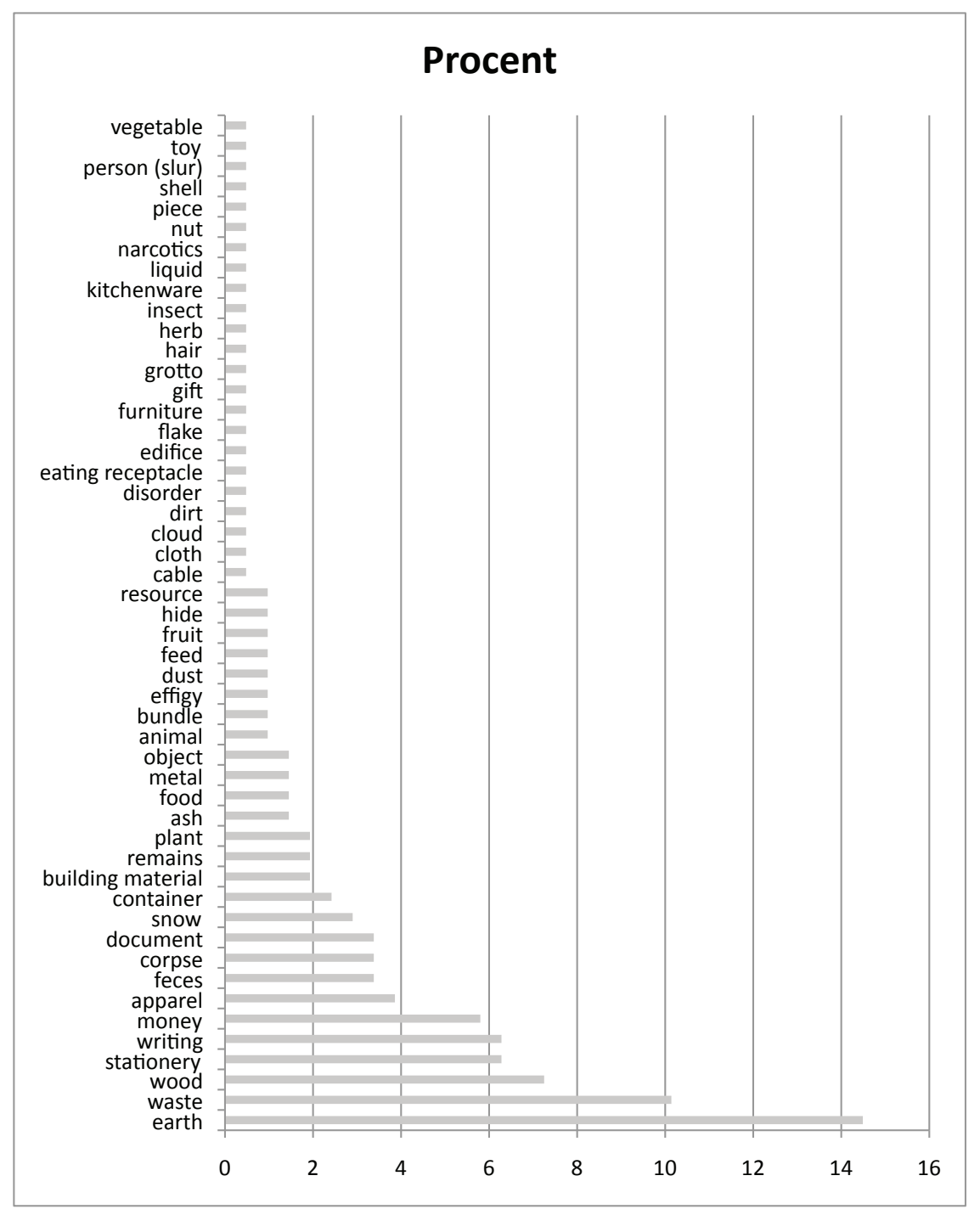

Fig. 6: Semantisk analyse af indre kollokater i pile of $\mathcal{N}$ 


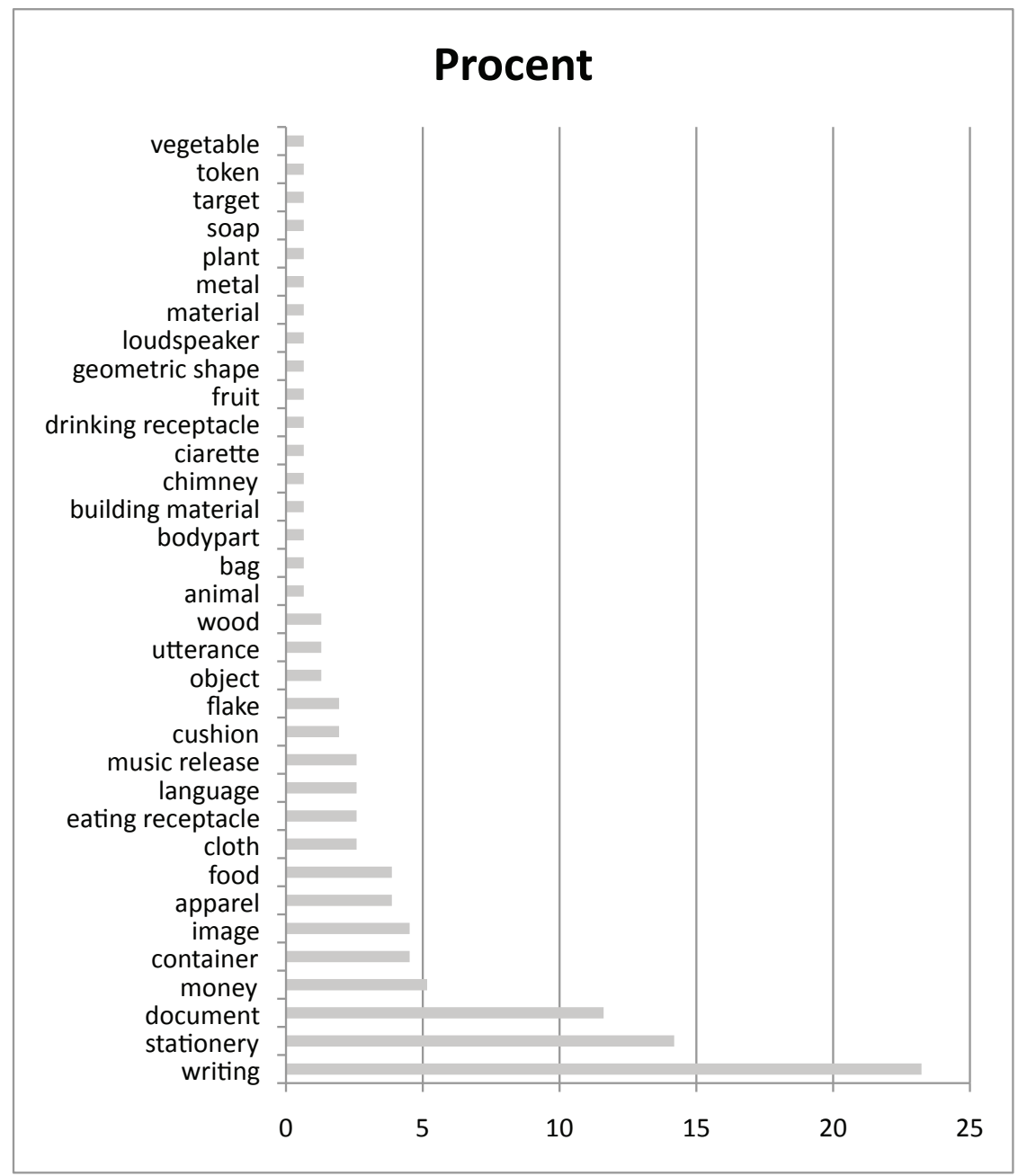

Fig. 7: Semantisk analyse af indre kollokater $i$ stack of $\mathcal{N}$ 
Her er tydelige sammenhænge mellem konstruktionernes konstellationsfunktioner og de semantiske klasser. For eksempel er de hyppigste klasser hos stack of $\mathcal{N}$ 'writing' (skrifter så som bøger og blade), 'document', 'stationary', 'money', 'image' (fysiske billedobjekter så som tegninger, malerier og fotografier), og 'music release' (fysiske musikmedier som CDer, vinylplader og kassettebånd). Alle disse klasser underordner kollokater, hvis referenter kan arrangeres i stacks ('stakke'). Nogle af disse klasser figurerer også i pile of $\mathcal{N}_{\mathrm{s}}$ indre kollokationsfelt, så som 'money', 'writing' og 'stationery', og her finder vi også 'earth' (f.eks sand, jord, grus og småsten), 'waste' og 'feces'. Vi har her tydeligvis at gøre med størrelser som kan arrangeres i piles ('bunker'). Det er også muligt at identificere en del lidt mere abstrakte indre semantiske prosodier som for eksempel:

- Stack of $\mathcal{N}$ : 'papirer' ('writing', 'document', 'stationery'), 'medier' ('image', 'music release'); 'beklædningsgenstande' ('apparel', 'cloth'), 'beholdere' ('container', 'eating receptable', 'drinking receptable').

- Pile of $\mathcal{N}$ : 'papirer' ('writing', 'document', 'stationery'), 'skidt/ affald' ('earth', 'waste', 'feces', 'dirt'), 'lig' ('corpse', 'remains').

Der synes i stack of $\mathcal{N}$ og pile of $\mathcal{N}$ at være en meget stærk sammenhæng mellem partitivernes konstellationsfunktioner, og det, som i Talmys (2000) terminologi kan kaldes de enkelte kollokaters referenters konfigurationelle strukturer. Cluster of $\mathcal{N}$, load of $\mathcal{N}$, og bunch of $\mathcal{N}$ virker mindre mønsterbunde i denne forstand. Dette skyldes dog, at konstellationerne ('klynge', 'læs' og 'bundt') ikke er bundne af konfigurationelle strukturer i samme grad (næsten alt kan arrangeres i klynger fra bygninger til galakser samt handlinger og mere abstrakte fænomener). Dog ser vi mange klasser i bunch of $\mathcal{N}_{\mathrm{s}}$ indre kollokationsfelt, som virker uforlignelige med 'bundt'-konstellationen, såsom 'person', 'time', 'occupation', 'liquid' og 'language'. Vi ser her også 'person (slur)' ('nedsættende personkategori') og 'disagreeable utterance'. Disse to klasser peger på, at bunch of $\mathcal{N}$ kan have en abstrakt negativ attitudinel indre prosodi (alle kan vel genkende udtryk som a bunch of jerks og $a$ bunch of nonsense). Det kan ikke udelukkes, at denne attitudinelle funktion udgør et område af konstruktionens usus, hvor andre semantiske forhold, såsom konfigurationel struktur underkendes, hvorfor udtrykket kan optræde sammen med semantiske klasser der ellers er uforlignelige med 'bundt'konstellationen. Load of $\mathcal{N}$ optræder med kollokater i klassen 'disagreeable utterance', og dette indikerer også en mulig negativ attitudinel funktion 
hvor en negativ holdning om et eller flere udsagn tilkendegives (velkendte eksempler er load of gibberish, load of crap, load of hogwash og load of bullshit).

Selvom vi er langt fra at kunne drage konklusioner omkring indre prosodier her, så er der da tegn på noget, der minder om indre semantisk prosodi. Hvad med ydre kollokater? Analyserne viser ingen tegn på prosodisksemantiske mønstre her.

\section{Afsluttende bemærkninger}

Kan grammatiske konstruktioner så have semantisk prosodi? Svaret må være, at det kan de måske godt. De to undersøgelser peger i retning af tegn på noget, som ligner semantisk prosodi, men der kan på nuværende tidspunkt ikke gives noget endegyldigt svar.

Forskningen, som ligger til grund for denne artikel har Frankensteinkarakter og er mest af alt eksplorativ med henblik på at se, om der i det hele taget er noget at komme efter. Der lader til at være lidt at komme efter, men for at der kan gøres noget ved det, kræver det, at konstruktionel semantisk prosodi deles op i en indre prosodi og en ydre prosodi, og at man opererer med indre og ydre kollokater og kollokationsfelter. Derudover bliver man nok nødt til at opgive den traditionelle skelnen mellem semantisk prosodi og semantisk præference, da det er umuligt at placere en klar skillelinje mellem de to.

Her er nok til en slags 'præ-hypotese' om konstruktionel semantisk prosodi, men denne er endnu ikke på et niveau, hvor den kan falsificeres eller verificeres. Den er dog substantiel nok til, at den i det mindste kan sættes op mod noget empiri. De to undersøgelser synes at vise, at konstruktioner kan have indre semantisk prosodi, hvorimod ydre semantisk prosodi ikke synes at være en særligt holdbar teoretisk konstrukt. De ydre mønstre, som den ganske vist eksperimenterende analyse identificerede, lader alle til at bygge på semantiske forbindelser mellem ydre og indre kollokater og ikke ydre kollokater og konstruktioner.

Jeg synes, skønt den underliggende forskning ikke peger på noget endegyldigt men snarere er den allerførste klirren med pipetter og reagensglas i Frankensteins laboratorium, mens Igor indhenter døde kropsdele, at undersøgelserne (og de overvejelser, som gjordes før og efter disse) viser, at der er noget at komme efter, og at det bestemt er værd at kigge nærmere på konstruktionel semantisk prosodi i fremtiden - specielt hvis man i et ususbaseret perspektiv anser sproget som et komplekst adaptivt konstruktionsnetværk, hvor kontekstuelle og ko-tekstuelle mønstre kan være en del af sprogsystemet. 


\section{Henvisninger}

Anthony, L. (2014). AntConc 3.4.4w. [software]

Begagić, M. (2013). Semantic preference and semantic prosody of the collocation make sense. Fezikoslovlje 14(2-3), 403-416.

Beckner, C., Ellis, N.C., Blythe, R., Holland, J., Bybee, J., Ke, J., Christiansen, M.H., Larsen-Freeman, D., Croft, W.A. \& Schoenemann, T. (2009). Language is a complex adaptive system. Language Learning 59(s1), 1-26. doi:10.1111/j.1467-9922.2009.00533.x.

Bick, E. (1996-2016). Visual interactive syntax learning. URL: http://visl.sdu. $\mathrm{dk}$ (lokaliseret 15/9-2016)

Bublitz, W. (1996). Semantic prosody and cohesive company: Somewhat predictable. Leuvense Bïdragen: Tijdschrïft voor Germaanse Filologie 85(1), 7-34.

Croft, W.A. (2001). Radical construction grammar: Syntactic theory in typological perspective. Oxford: Oxford University Press.

Croft, W.A. (2003). Lexical rules vs. constructions: A false dichotomy. I: Motivation in language: Studies in honour of Günter Radden. Cuyckens, H., Berg, T., Dirven, R. \& Panther, K.-U. (red.). Amsterdam: John Benjamins, 49-68.

Davies, M. (2016). Corpus of Contemporary American English. URL: http:// corpus.byu.edu/coca (lokaliseret 10/9-2016).

Fillmore, G.J., Kay, P. \& O’Connor, M.C. (1988). Regularity and idiomaticity in grammatical constructions: the case of let alone. Language 64(3), 501-539.

Fillmore, C.J. (1988). The mechanics of "Construction Grammar". BLS $14,35-55$.

Frank, R.M. (2015). A future agenda for research on language and culture. I: The Routledge handbook of language and culture. Sharifian, F. (red.). New York: Routledge, 493-512.

Goldberg, A.E. (1995). Constructions: A construction grammar approach to argument structure. Chicago: Chicago University Press.

Hjulmand, L.-L. \& Schwarz, H. (2015). A concise contrastive grammar of English for Danish students (4. rev. udg.). Frederiksberg: Samfundslitteratur.

Hopper, P.J. (1998). Emergent grammar. I: The new psychology of language: Cognitive and functional approaches to language structure. Tomasello, M. (red.). Mahwah, NJ: Lawrence Erlbaum, 155-175.

Hunston, S. \& Francis, C. (1999). Pattern grammar: The principles and practices of corpus-driven grammar. Amsterdam: John Benjamins.

Jensen, K.E. (2016). A great deal of evidence based on a great many instances: A usage-based comparative study of two English nominal constructions. Oplæg v. $6^{\text {th }}$ UK Cognitive Linguistics Conference, Bangor University, 21/6-2016. 
Jensen, K.E. (2017). Corpora and cultural cognition: How corpus-linguistic methodology can contribute to Cultural Linguistics. I: Advances in Cultural Linguistics. F. Sharifian (red.). New York: Springer, 477-506.

Louw, B. (1993). Irony in the text or insincerity in the writer? The diagnostic potential of semantic prosodies. I: Text and technology: In honour of Fohn Sinclair. Baker, M., Francis, G. \& Tognini-Bonelli, E. (red.). Amsterdam: John Benjamins, 157-175.

Louw, B. (2000). Contextual prosodic theory: Bringing semantic prosodies to life. I: Words in context: In honour of John Sinclair. Heffer, C. \& Saunston, H. (red). Birmingham: ELR, 48-94.

Partington, A. (2004). "Utterly content in each other's company": Semantic prosody and semantic preference. International Fournal of Corpus Linguistics 9, 131-156.

Patten, A.L. (2014). The historical development of the it-cleft: A comparison of two different approaches. I: Theory and data in cognitive linguistics. Gisborne, N. \& Hollmann, W.B. (red.). Amsterdam: John Benjamins, 87-114.

Sinclair, J. (1991). Corpus, concordance, collocation. Oxford: Oxford University Press.

Sinclair, J. (1996). The search for units of meaning. Textus 9, 75-106.

Stewart, D. (2010). Semantic prosody: A critical evaluation. New York: Routledge.

Stubbs, M. (2001). Words and phrases: Corpus studies of lexical semantics. Oxford: Blackwell.

Talmy, L. (2000). Toward a cognitive semantics, vol. 1: Concept structuring systems. Cambridge, MA: MIT Press.

Tognini-Bonelli, E. (2001). Corpus linguistics at work. Amsterdam: John Benjamins.

Tomasello, Michael (2003). Constructing a language: A usage-based theory of language acquisition. Cambridge, MA: Havard University Press. 